\title{
Development of Authentic Assessment Models in Research Methods Courses
}

\author{
Sri Wahyuni ${ }^{1,}$ Fertilia Ikashaum ${ }^{1, *}$ Endah Wulantina ${ }^{1,}$ Juitaning Mustika ${ }^{1,}$ Laila \\ Mustika Putri ${ }^{1}$
}

\author{
${ }^{1}$ State Islamic Institute of Metro \\ *Corresponding author.Email: ikashaum@gmail.com
}

\begin{abstract}
Assessment is one of the learning processes used to see the success of learning. If the assessment system is correct, then the data obtained will describe the actual learning outcomes. This research aims to produce an authentic assessment model used as an assessment guide for research methods courses. The assessment model contains authentic tasks that can lead students to apply theory to structured research ideas in a good research proposal design. This assessment model consists of 5 aspects which have translated into 21 sub-aspects with 48 assessment items. This research uses design research with the type of development study. The stages carried out are preliminary and formative evaluations which include self-evaluation, prototyping, and field testing. The subjects in this study were eight lecturers who taught research methods courses. The results showed that the authentic assessment model developed had valid and reliable characteristics.
\end{abstract}

Keywords: Assessment Guidelines, Authentic Assessment Model, Research Methods.

\section{INTRODUCTION}

Assessment is one of the activities that cannot be separated from the learning process in education [1], [2]. The success of a learning process can be seen through assessment [3]. The assessment results will reflect the achievement of a learning goal carried out by educators, which is one indicator of educational goals. Therefore, the assessment carried out by the teacher must genuinely reflect the results of the learning process that has been carried out [4].

Nitko and Brookhart [5] define assessment as the process of gathering information to make decisions about students, curriculum, programs, and schools, and education policy. One of the functions of the assessment is to see the quality of learning [6]. Efforts to improve education quality can be made by improving the quality of learning and its assessment system. If the learning outcomes assessment system is sound, the data obtained will also be accurate, i.e., describing the actual results.

The assessment system currently developed is the authentic assessment system [7]. Authentic assessment is also known as a performance assessment based on students' performance [8][9]. Nurgiyantoro [10] states that the pressure of competency achievement is not on the knowledge mastered by students but on the ability of students to display, demonstrate, or do something that is a reflection of the essence of the knowledge and abilities they have mastered.

Authentic assessment is carried out at the basic education level and in higher education [11]. At the tertiary level, an authentic assessment is used to guide lecturers to see the learning outcomes in the courses taught [12][13], either process assessment or final results. However, there are several obstacles experienced in conducting student assessments [14]. The first obstacle is when conducting a comprehensive and consistent assessment. The second obstacle is the difficulty in developing authentic instruments. At the tertiary level, an authentic assessment is used to guide lecturers to see the learning outcomes in the courses taught, either process assessment or final results.

There are four types of authentic assessment, namely performance appraisal, project appraisal, portfolio assessment, and written assessment [15]. Project assessment aims to assess the results of student work given within a certain period. The results of interviews with several lecturers at IAIN Metro indicate that some 
courses do not have specific guidelines or references in assessing student work. So far, the assessment process only aims at learning outcomes; namely, students can do a series of tasks given by the lecturer. Assessment does not include process and performance assessments based on authentic tasks relevant to everyday life or today's real-world challenges.

One of the courses has an essential role for students in the Research Methods course. After completing this course, students expect to explain and apply research concepts and steps; students can design research by the existing steps. In addition, this Research Methods course is a reference for students in completing their final project in the form of a thesis. Therefore, the role of the research method course is very significant for students [16], so the assessment made for this course must also be precise so that the assessment results obtained truly describe the actual abilities of students in terms of the process and final results, namely cognitive, affective, and psychomotor.

Based on the description of these problems, it is necessary to develop an authentic assessment model for the tarbiyah and teacher training faculties at IAIN Metro. This development research is expected to help educators assess students, namely lecturers in the Research Methods course. The product results in an authentic assessment model are expected to be a guideline or reference for assessment so that the assessment results will describe accurate data. In addition, with this authentic assessment model, students will know the material studied and the application of the theory given

\section{METHODS}

This research is a design research type of development study. The research subjects consisted of 8 lecturers who taught research methodology courses. The entire classes taught by these lecturers are 21 classes with an average number of students per class as many as 30 people. The research was carried out in the odd semester of the 2019/2020 academic year. The final product is an authentic assessment model to assess student research proposal projects with 17 sub-aspects and 43 assessment criteria. The research model refers to the Tessmer model with preliminary and formative evaluation stages [17]. The formative evaluation stage includes the self-evaluation, prototyping (expert review, one-to-one, and small group) stages and field tests.

The data collection and analysis stages were in walkthroughs, observations, interviews, and tests. The walkthrough was carried out to collect suggestions and comments from expert reviews to assess the authentic assessment model made. Expert reviews involved in this research are evaluation and research method experts, measurement and assessment experts, and linguists.
Observations were made to determine the needs of lecturers for assessment instruments in research methodology courses. Observations were also carried out at the small group and field test stages to see the accuracy of the assessment model. Interviews were conducted at the small group and one-to-one stages to see the lecturer's response when using an authentic assessment model to assess student research proposals. The data obtained were then analyzed descriptively.

\section{RESEARCH RESULTS}

This study aims to develop an authentic assessment model instrument in the research methodology course. To obtain the assessment model have the steps are described as follows:

\subsection{Preliminary Design}

This research begins with the preliminary stage contains a needs analysis of the assessment model instrument. Curriculum studies, relevant theories, previous research results, and research methodology materials were conducted to obtain an initial draft framework for the assessment model. The researcher determines the research subjects, namely eight lecturers who teach research methodology courses.

\subsection{Self Evaluation}

The form of authentic assessment developed is a student project assessment regarding the making of a research proposal. This research procedure is carried out by developing a product in an authentic assessment guide to measure student work in a research proposal. Student research proposals that assessed using this research product are student proposals that use quantitative research.

The initial draft of this authentic assessment model is in the form of assessment aspects of student research proposals which then developed into the main instrument in the form of an authentic assessment model. This assessment model consists of five aspects that serve as assessment guidelines.

These systematic writing aspects consist of 2 subaspects with 12 items of assessment instruments, namely; chapter I consists of 6 sub-aspects with 14 items of assessment instruments, then chapter II consists of 2 sub-aspects with five items of assessment instruments, Chapter III consists of four sub-aspects with six items of assessment instruments. The bibliography consists of one sub-aspects with two items of assessment instruments. The result of this initial draft is called prototype one. 


\subsection{Expert Review}

At this stage, prototype one is analyzed by expert review. Three expert reviewers carried out the analysis to assess the extent to which the instrument items were relevant or by the assessment indicators. The three people provided corrections or input regarding the preparation of good instrument items. Table 1 shows the results of comments and suggestions at the Expert Review
Stage.

Table 1. Results of comments and suggestions at the Expert Review Stage

\begin{tabular}{|l|l|}
\hline \multicolumn{1}{|c|}{ Expert review } & \multicolumn{1}{c|}{ Comments and Suggestions } \\
\hline Research methods and evaluation expert & $\begin{array}{l}\text { Add assessment items in Chapter II and bibliography. } \\
\text { Chapter II should add a hypothetical sub-aspect for this } \\
\text { type of quantitative research. The bibliography should be } \\
\text { added to the instrument in conformity to writing a } \\
\text { bibliography with a predetermined guidebook. }\end{array}$ \\
\hline Measurement and appraisal expert & $\begin{array}{l}\text { Add Chapter I with relevant research sub-aspects along } \\
\text { with assessment items. }\end{array}$ \\
\hline Linguist & $\begin{array}{l}\text { In every aspect of improving language and writing that is } \\
\text { still not right, it is necessary to make it easy to understand } \\
\text { when used. In the scoring section, additional information } \\
\text { in the form of a scale is added: if the proposal made by } \\
\text { students on each item is very precise given a score of } 4, \\
\text { correctly it is given a score of 3, less precise is given } \\
\text { score 2, and inappropriate gave a score 1. }\end{array}$ \\
\hline
\end{tabular}

Furthermore, comments and suggestions from the expert review are guide researchers to revise the assessment model.

\subsection{One-to-One}

The revised expert review prototype one results tested on one lecturer in charge of research methodology courses to assess student research proposal projects. The results obtained from this stage are the lack of hypothetical sub-aspects in Chapter 2. Table 2 shows the results of the one-to-one stage, along with the results of the revision.

Table 2. Revision results for one-to-one stage

\begin{tabular}{|c|c|c|c|c|c|}
\hline \multicolumn{3}{|r|}{ Before Revision } & \multicolumn{3}{|r|}{ After Revision } \\
\hline \multirow[t]{8}{*}{$\begin{array}{l}\text { CHAPTER } \\
\text { II } \propto\end{array}$} & \multirow[t]{3}{*}{ Theory-Studya } & $\begin{array}{l}\text { The suitability of the theoretical study with the variables or } \\
\text { problems to be studied }\end{array}$ & \multirow[t]{7}{*}{$\begin{array}{c}\text { CHAPTER } \\
\Pi \propto\end{array}$} & \multirow[t]{3}{*}{ Theory-Studya } & $\begin{array}{l}\text { The suitability of the theoretical study with the variables -or } \\
\text { problems to be studiedrs }\end{array}$ \\
\hline & & Use-of-accredited journals and reference books - in -citations: & & & Use-of-accredited journals-and reference-books in-citations : \\
\hline & & $\begin{array}{l}\text { Compilation of theoretical-conclusions quoted in their-own } \\
\text { words } a\end{array}$ & & & $\begin{array}{l}\text { Compilation - of theoretical-conclusions quoted in their -own- } \\
\text { words } x\end{array}$ \\
\hline & \multirow[t]{5}{*}{ Framework } & $\begin{array}{l}\text { The suitability - of the flow- of the theoretical framework- } \\
\text { with the research to be carried-outa }\end{array}$ & & \multirow[t]{2}{*}{ Frameworka } & $\begin{array}{l}\text { The suitability of the flow- of the theoretical- framework- } \\
\text { with the research to be carried outa }\end{array}$ \\
\hline & & $\begin{array}{l}\text { The -suitability of the framework of thought with the theory } \\
\text { that has been - studiedx }\end{array}$ & & & $\begin{array}{l}\text { The -suitability - of the framework - of thought with the theory- } \\
\text { that has -been-studiedx }\end{array}$ \\
\hline & & & & \multirow{2}{*}{$\begin{array}{l}\text { Hypothesis- } \\
\text { (quantitative)a }\end{array}$} & Contains answers to the formulation of the problem a \\
\hline & & & & & $\begin{array}{l}\text { The suitability of the hypothesis with the formulation of the } \\
\text { problem that has been prepared a }\end{array}$ \\
\hline & & & & & Total:Scorex \\
\hline
\end{tabular}

The sub-aspects of the hypothesis added two items of assessment instruments, namely, containing the answers to the problem formulation and suitability of the hypothesis with the formulation of the problem that has been prepared.

\subsection{Small Group}

The assessment model was revised based on input from expert reviews and one-to-one results and was called prototype 2 . Then in the small group stage, the assessment model was given to 3 lecturers who taught research methodology courses; from the test results known that the assessment model still has limitations. Some student proposals contain relevant research aspects, while prototype 2 developed does not cover these aspects, so the product needs to be revised. Relevant research is the result of previous research that can be used to compare the research to be carried out. Table 3 shows the revised results from the small group stage. 
Table 3. Results of the small group stage revision Before Revision

\begin{tabular}{|c|c|}
\hline \multirow[b]{2}{*}{ CHAPTER·I $\propto$} & After Revision \\
\hline & CHAPTER·I $\propto$ \\
\hline -backgroundx & -backgrounda \\
\hline --identification -of problems $\alpha$ & --identification-of problems \\
\hline -formulation of the problem $x$ & -formulation of the problem \\
\hline --scope-of problem $\alpha$ & -scope-of problem $x$ \\
\hline -research purposes $\alpha$ & -research purposes $x$ \\
\hline \multirow[t]{2}{*}{-benefits of research $x$} & -benefits-of-research $x$ \\
\hline & -relevant-research $\propto$ \\
\hline
\end{tabular}

The revised result of the small group stage is called prototype 3 .

\subsection{Field Test}

At the field test stage, prototype three was tested on eight lecturers who teach research methodology courses. Of the eight lecturers, there are approximately 21 classes, with each class containing 30 students. The assessment model is used to assess student research proposals. In general, the assessment model is good, and no further revision is needed. The final product of this research is an authentic assessment model in the research methods course for student project assessment in the form of a research proposal. Overall there are 21 sub-aspects with 48 assessment criteria. The assessment model has also met the valid and reliable criteria seen from Aiken's V validity test and the ICC reliability test (Inter-rater coefficient). Table 4 shows the results of the validity and reliability tests.

The table shows that each assessment item in the authentic assessment model can already represent the assessment and is relevant to the aspects of the assessment used. In addition, this authentic assessment model meets consistent or reliable values. Each aspect of the instrument has its percentage of assessment to represent the proportion of research proposal writing, namely systematic writing $10 \%$, chapter $130 \%$, chapter $225 \%$, chapter $330 \%$, and bibliography $5 \%$.

Table 4. Product Validity and Reliability Test Results

\begin{tabular}{|l|l|l|}
\hline Test & Value Test & Description \\
\hline Validity & 0,98 & Valid \\
\hline Reliability & 0,95 & Reliable \\
\hline
\end{tabular}

\section{CONCLUSION}

The final instrument produced in this study is an assessment model equipped with guidelines/descriptions for the assessment of instrument items and an assessment rubric using a Likert scale to assess research proposals made by students. The aspects assessed in the development of an authentic assessment model in the research method course consist of 5 aspects of assessment, namely the systematic aspect of writing, Chapter I, Chapter II, Chapter III, and bibliography. The overall assessment model has met good validity and reliability.

\section{AUTHOR CONTRIBUTION}

All authors conceived and designed this study. All authors contributed to the process of revising the manuscript, and at the end all authors have approved the final version of this manuscript.

\section{REFERENCES}

[1] W. Maba, “Teacher's perception on the implementation of the assessment process in 2013 curriculum," Int. J. Soc. Sci. Humanit, 1(2) 1-9 (2017). DOI: 10.29332/ijssh.v1n2.26

[2] Z. Yan, D. Boud, Assessment as Learning: Maximising Opportunities for Student Learning and Achievement. Routledge, 2021.

[3] D. Wiliam, "What is assessment for learning?," Stud. Educ. Eval., 37(1) 3-14 (2011). DOI: 10.1016/j.stueduc.2011.03.001.

[4] S. Schechtel, V. Mozol, M. Clapson, B. Gilbert, J. Tran, S. White, "The name of the game: utilizing experiential learning in the classroom to engage, empower and reflect on student learning and assessment" Pap. Postsecond. Learn. Teach., 4 1724 (2020). URL: https://journalhosting.ucalgary.ca/index.php/pplt/art icle/view/68856.

[5] S.M. Brookhart, A. J. Nitko, Assesment and Grading in Classrooms. Upper Saddle River: Pearson, 2008.

[6] A. Kanjee, Y. Sayed, “Assessment policy in postapartheid South Africa: Challenges for improving education quality and learning," Assess. Educ. Princ. Policy Pract., 20(4), 442-469, (2013). DOI: 10.1080/0969594X.2013.838541.

[7] C. Rapanta, L. Botturi, P. Goodyear, L. Guàrdia, M. Koole, "Online University Teaching During and After the Covid-19 Crisis: Refocusing Teacher 
Presence and Learning Activity," Postdigital Sci. Educ., 2(3) 923-945 (2020). DOI: 10.1007/s42438020-00155-y.

[8] R.J. Musa, A. I. Erhivwode, "Attitude of English Language Teachers Towards Authentic Assessment in Senior Secondary Schools in Delta State", J. Guid. Couns. Stud., 5(1) 13-21 (2021). URL: http://www.jgcsunizik.org/Vol-

5,\%20Issue\%201,\%202021/Musa\%20\%20\&\%20Er hivwode.pdf

[9] S.E. Martika, M. Zaim, "The implementation of authentic assessment on reading comprehension of the tenth grade students of SMAN 8 Padang", J. English Lang. Teach., 10(1) 129-137 (2021). DOI: 10.24036/jelt.v10i1.111679.

[10]B. Nurgiyantoro, "Model Penilaian Otentik dalam Pembelajaran Bahasa" Litera J. Penelit. Bahasa, Sastra, dan Pengajarannya, 10(2) 114-125 (2011). DOI: $10.21831 /$ ltr.v10i2.1157

[11] T.W. Maxwell, "Assessment in higher education in the professions: action research as an authentic assessment task," Teach. High. Educ., 17(6) 686696 (2012). DOI: 10.1080/13562517.2012.725220

[12]F. Martin, A. Ritzhaupt, S. Kumar, K. Budhrani, "Award-winning faculty online teaching practices: Course design, assessment and evaluation, and facilitation," Internet High. Educ., 42(November 2018) 34-43 (2019). DOI: 10.1016/j.iheduc.2019.04.001.

[13]F. Martin, K. Budhrani, C. Wang, "Examining faculty perception of their readiness to teach online," Online Learn. J., 23(3) 97-119 (2019). DOI: $10.24059 /$ olj.v23i3.1555

[14] S. Ermawati and H. Taufiq, "Penilaian Autentik dan Relevansinya dengan Kualitas Hasil Pembelajaran (Persepsi Dosen dan Mahasiswa IKIP PGRI Bojonegoro)", J. Pendidik. Ilmu Sos., 27(1) 92-103 (2017). DOI: 10.2317/jpis.v27i1.5123?CITATIONS? total citations on Dimensions.

[15] P. Winograd, F. D. Perkins, "Authentic assessment in the classroom: Principles and practices", in A handbook for student performance assessment in an era of restructuring, 1-11 (1996).

[16]F. Martin, D.U. Bolliger, "Engagement matters: Student perceptions on the importance of engagement strategies in the online learning environment," Online Learn. J., 22(1) 205-222 (2018). DOI: 10.24059/olj.v22i1.1092

[17] M. Tessmer, Planning and Conducting Formative Evaluation, Kogsn Page Limited, 1993. 